Available online on 15.08.2020 at http://jddtonline.info
Open Access to Pharmaceutical and Medical Research

Open Access

Research Article

\title{
Costus afer modulates the activities of glycolytic and gluconeogenic enzymes in streptozotocin induced diabetic rats
}

\author{
Armelle D. Tchamgoue ${ }^{1,2}$, Paul D. D. Dzeufiet ${ }^{3}$, Jules-Roger Kuiate ${ }^{2}$, Gabriel A. Agbor ${ }^{1 *}$ \\ 1. Centre for Research on Medicinal Plants and Traditional Medicine, Institute of Medical Research and Medicinal Plants Studies, P.O. Box \\ 13033, Yaoundé Cameroon \\ 2. Research Unit of Microbiology and Antimicrobial Substances, University of Dschang, P.0 Box 67 Dschang, Cameroon \\ 3. Laboratory of Animal Biology, University of Yaounde, P.O. Box 812 Yaounde, Cameroon
}

\begin{abstract}
Background: Glycolytic enzymes (Hexokinase and $\alpha$-glucosidase) and gluconeogenic enzymes (Glucose-6-phosphatase and fructose-1,6disphosphatase) control carbohydrate metabolism and hence glucose hemostasis, an important approach for the control of diabet es. The present study was carried out to evaluate the effect of hydro-ethanolic leaf extract of Costus afer on these enzymes.

Materials and methods: Streptozotocin-induced diabetic rats were administered hydro-ethanolic leaf extract of Costus afer (250, 500 and $1000 \mathrm{mg} / \mathrm{kg}$ body weight) orally for 8 weeks. Effect of the extract was monitored on the decrease in glycemia and the modulatory activities on glycolytic and gluconeogenic enzymes activities. The pancreas was also immunohistochemically examined for regeneration of the Islet cells.

Results: Hydro-ethanolic extract significantly decreased the blood glucose concentration, serum glucose-6-phosphatase and fructose-1,6disphosphatase activities which were associated with an increase in the activity of hexokinase in the liver and kidney. immunohistochemical examination of the pancreas, revealed the preservation and regeneration of the islet of the Langerhans cells.
\end{abstract}

Conclusion: Thus, $C$. afer acts against hyperglycemia modulating the activities of glucose-6-phosphatase, fructose-1,6-bisphosphatase and hexokinase, and regeneration of $\beta$-cells.

Keywords: Costus afer, gluconeogenic enzymes, glycolytic enzymes, streptozotocin, $\alpha$-glucosidase.

Article Info: Received 18 June 2020; Review Completed 12 July 2020; Accepted 19 July 2020; Available online 15 August 2020

\section{Cite this article as:}

Tchamgoue AD, Dzeufiet PDD, Kuiate JR, Agbor GA, Costus afer modulates the activities of glycolytic and gluconeogenic enzymes in streptozotocin induced diabetic rats, Journal of Drug Delivery and Therapeutics. 2020; 10(4-s):63-70 http://dx.doi.org/10.22270/jddt.v10i4-s.4270

\section{*Address for Correspondence:}

Gabriel A. Agbor, Centre for Research on Medicinal Plants and Traditional Medicine, Institute of Medical Research and Medicinal Plants Studies, P.O. Box 13033, Yaoundé Cameroon

\section{INTRODUCTION}

Carbohydrates are key players in metabolic processes of living organisms serving as the main energy sources and as structural elements in living cells. The main end product of carbohydrate is glucose which is the energy currency in almost all living cells and tissues with emphasis placed on its synthesis, degradation, and storage. Glycolysis and tricarboxylic acid cycle are the energy generating pathways of carbohydrate metabolism. In this process, a small amount of energy is released when glucose molecule is converted to two pyruvate molecules. When the glucose concentration is high glycogenesis (glycogenic pathway) is employed for the synthesis of glycogen which can be degraded by glycogenolysis (glycolytic pathway) when glucose is in short supply. Some non-carbohydrate precursors have been known to synthesize glucose through gluconeogenesis $\mathbf{1}$. If glucose produced is not required in for immediate energy use, then they are stored as glycogen in liver and muscle. In this way the cell regulates glucose concentration in the body.

Diabetes mellitus is a major public health problem in the developed as well as developing countries. It was classified seventh among the leading causes of death, and third when it's fatal complications are taken in to considerations 2 . Diabetes mellitus (DM) is defined as a state in which homeostasis of carbohydrate and lipid metabolism is improperly regulated by insulin ${ }^{3}$. It is a group of heterogenous, hormonal and metabolic disorders characterized by hyperglycemia and glucosuria with disturbances of carbohydrates, fat and protein metabolism resulting from defects in insulin secretion and or insulin action 4. Defects in carbohydrate metabolizing and consistent efforts of the physiological systems to correct the 
imbalance in carbohydrate metabolism place an over exertion on the endocrine system, which leads to the deterioration of endocrine control. For the maintenance of normoglycemic status, there must be a coordinated regulation of several metabolic pathways including gluconeogensis and glycolysis ${ }^{5}$. This presents a moving therapeutic target that requires different agents to address the different features of the disease 6 . The prevalence of diabetes is on the rise and WHO has predicted that by 2030 the number of adults with diabetes will double worldwide, from 177 million in 2000 to 370 million. The estimated worldwide prevalence of diabetes among adults in 2010 was 285 million (6.4\%) and this value is predicted to rise to around 439 million (7.7\%) by 20307.

Many diabetic treatments have been developed in the past decades with the same underlying goal to maintain adequate blood glucose concentration. To date, there are six classes of oral antidiabetic agents which are being used in the treatment of diabetes mellitus. These include sulfonylureas and meglitinides, biguanides, thiazolidinediones, $\alpha$ glucosidase inhibitors and dipeptidylpeptidase-4 inhibitors 8,9. Each of these drugs class exerts on different mechanism of action, including stimulation of insulin secretion, reduction of hepatic gluconeogenesis, increasing peripheral insulin sensitivity, delaying intestinal digestion and absorption of carbohydrate, and increasing endogenous levels of incretin hormones that act in the presence of glucose to stimulate insulin secretion 8,9. Unfortunately, these agents have side effects, such as hypoglycemia, weight gain, lactic acidosis, vitamin B12 deficiency, gastrointestinal problems and pancreatitis 10-12.

Traditionally, antidiabetic plants might provide a useful source of new oral hypoglycemic compounds for development as phytomedicine or as simple dietary adjuncts to existing therapies 13. Costus afer Ker gawl (family zingiberacae) also known locally as "sugar twins", is found easily in Tropical Africa. Traditionally, C. afer have been known to possess high medicinal values and is being used for the treatment of eruptive fevers, rash, cough, hypertension and diabetes. Recent studies have revealed that $C$. afer has a potent inhibiting effect on alpha-amylase and alpha-glucosidase with antioxidant capacities 14. In another study, we showed that $C$. afer inhibit glucose uptake and possess anti-lipidemic capacities 15. However, little is known about its effect on glycolytic and gluconeogenic enzymes which play a significan role in glucose metabolism. Thus the present study tests the hypothesis that hydroethanolic leaf extract of $C$. afer possess antidiabetic activity by inhibiting the activity of glucose-6-phosphatase and fructose-1,6-disphosphatase and increasing hexokinase activity.

\section{MATERIALS AND METHODS}

\section{Chemicals}

The chemicals used for the study were of analytical grade. Streptozotocin, metformin, trichloroacetic acid (TCA), ammonium molybdate, ferric sulfate, citrate buffer, glucose, ATP, magnesium chloride, potassium chloride, Tris-HCl buffer, fructose-1,6-diphosphate, EDTA were purchased from Sigma-Aldrich Chemie GmbH Kappelweg 1D-91625 Schnelldorf German.

\section{Preparation of Costus afer extracts}

The leaves of $C$. afer were extracted with hydro-ethanolic (20:80) solvent. Fresh leaves of C. afer were washed, weighed and dried in an oven at $50{ }^{\circ} \mathrm{C}$ for 3 days. After drying the leaves (1400 g) were grounded and extracted with $5 \mathrm{~L}$ of hydro-ethanolic solvent for 72 hours. The extract was filtered and concentrated with the aid of a rotary evaporator and freeze dried. The freeze dried sample was used for the study.

\section{Animals}

Male Wistar rats weighing between 180 and $200 \mathrm{~g}$ were used in this study. The rats were raised in the Laboratory of Pharmacology of the Centre for Research on Medicinal Plants and Traditional Medicine, Yaoundé-Cameroon and housed in wire meshed ( 3 per cage) cages and maintained at $24 \pm 2^{\circ} \mathrm{C}$ temperature and a cycle of 12:12 hours light/dark with free access to food and water at all time. This study was carried out in line with the practice and principles of the institution on the use of experimental animals respecting the 2011 Guide for the Care and Use of Laboratory Animals, 8th edition and the Animal Welfare Act.

\section{Induction of diabetes}

After acclimatiation into the laboratory conditions for one week, the rats were made diabetic by a single intraperitoneal injection of streptozotocin $(60 \mathrm{mg} / \mathrm{kg}$ body weight) freshly dissolved in cold saline $(0.9 \% \mathrm{NaCl})$ after $16 \mathrm{~h}$ of fasting. To overcome the initial hypoglycemic shock, rats were administered $5 \%$ glucose solution ad libitum for $24 \mathrm{~h}$. Diabetes was confirmed in these rats 7 days after streptozotocin injection. Rats with fasting blood glucose level exceeding $200 \mathrm{mg} / \mathrm{dL}$ were considered to be diabetic and included in the study $\mathbf{1 6}$.

\section{Experimental design}

After the successful induction of experimental diabetes, the rats were divided into six groups of six rats each as follow:

Group I: normal control rats (distilled water)

Group II: diabetic control rats (distilled water)

Group III: diabetic rats treated with $250 \mathrm{mg} / \mathrm{kg}$ C. afer (DHE 250),

Group IV: diabetic rats treated with $500 \mathrm{mg} / \mathrm{kg}$ C. afer (DHE 500),

Group V: diabetic rats treated with $1000 \mathrm{mg} / \mathrm{kg}$ C. afer (DHE 1000),

Group VI: diabetic rats treated with $500 \mathrm{mg} / \mathrm{kg}$ metformin (MET 500).

All administrations were oral and lasted 8 weeks during which food and water consumption and body weight of experimental mice were monitored. Blood glucose level was measured weekly during the experimental period.

\section{Sacrifice of rats and preparation of tissue homogenate}

At the end of 8 weeks, the experimental animals were fasted for 12 hours then taken into a separate room where they were weighed and blood samples collected under pentobarbital sodium anesthetized (humane pharmaceutical grade, $78 \mathrm{mg} / \mathrm{kg}$ of body weight administered intraperitonially). The animal was fixed on a dissecting board and incised mid-ventrally for the collection of the pancreas, small intestine, liver and kidneys. The tissues except the pancreas (kept for histochemistry) were excised, freed of surrounding tissues, blotted with clean tissue paper, weighed and homogenized in ice phosphate buffer $(0.1 \mathrm{M}$, $\mathrm{pH} 7.4)$, to obtain $10 \%$ homogenate $(\mathrm{w} / \mathrm{v})$. The homogenates were centrifuged at $8000 \mathrm{rpm}$ for 10 minutes with the aid of a refrigerated centrifuge at $4^{\circ} \mathrm{C}$ to obtain the supernatants and kept frozen $\left(-20^{\circ} \mathrm{C}\right)$ before being used for biochemical analysis. 


\section{Determination of enzymes activities}

\section{Assay of intestinal $\alpha$-glucosidase (EC 3.2.1.20) activity}

The isolated small intestine was cut longitudinally, rinsed with ice-cold saline and homogenized in $10 \mathrm{ml}$ saline $(0.9 \%$ $\mathrm{NaCl})$. Aliquots of homogenate were then incubated with $\mathrm{p}$ nitrophynyl glucopyranoside $(5 \mathrm{mM}$ in $20 \mathrm{mM}$ phosphate buffer, $\mathrm{pH}$ 6.9). The reaction mixture was incubated at $37{ }^{\circ} \mathrm{C}$ for 20 minutes and stopped by adding $2 \mathrm{ml}$ of $0.1 \mathrm{M} \mathrm{Na}_{2} \mathrm{CO}_{3}$. The $\alpha$-glucosidase activity was determined by measuring the yellow colored p-nitrophenol released from pNPG at $400 \mathrm{~nm}$ 17. Enzymatic activity expressed in $\mu \mathrm{mol} / \mathrm{L}$ of released product/mg of protein as determined from the standard curve of p-nitrophenol solution ( $5 \mathrm{mM})$.

\section{Assay of hepatic and renal hexokinase activity}

Tissue hexokinase (EC 2.7.1.1) was assayed by the method of Brandstrup et al. ${ }^{18}$. To $1 \mathrm{~mL}$ of glucose was added $0.5 \mathrm{~mL}$ of adenosine triphosphate (ATP), $0.1 \mathrm{~mL}$ of magnesium chloride, $0.4 \mathrm{~mL}$ of potassium dihydrogen phosphate, $0.4 \mathrm{~mL}$ of potassium chloride, $0.4 \mathrm{~mL}$ of sodium fluoride and $2.5 \mathrm{~mL}$ of Tris- $\mathrm{HCl}$ buffer and this mixture was preincubated at $37^{\circ} \mathrm{C}$ for $5 \mathrm{~min}$. The reaction was initiated by the addition of $2 \mathrm{~mL}$ of tissue homogenate. $1 \mathrm{~mL}$ of the reaction mixture was immediately transferred into a tube containing $1 \mathrm{~mL}$ of $10 \%$ TCA that was considered as zero time. A second aliquot was removed and transferred in to another tube containing $1 \mathrm{~mL}$ of $10 \%$ TCA after $30 \mathrm{~min}$ incubation at $37^{\circ} \mathrm{C}$. The protein precipitate was removed by centrifugation and the residual glucose in the supernatant was estimated ${ }^{19}$. Enzymatic activity was expressed in $\mu \mathrm{mol} / \mathrm{L}$ of phosphorylated glucose $/ \mathrm{min} / \mathrm{mg}$ of protein. Phosphorylated glucose was obtained from these equations:

Free glucose $=($ OD sample $/$ OD standard $) *[$ standard $](1)$ [Phosphorylated glucose $](\mu \mathrm{mol} / \mathrm{L})=$

[Glucose in reaction] - [Free glucose] (2)

\section{Assay of hepatic and renal glucose-6-phosphatase} activity:

Activity of glucose-6-phosphatase (EC 3.1.3.9) was measured by the method of Koida and Oda 20 . To $0.7 \mathrm{~mL}$ of citrate buffer $(0.1 \mathrm{~mol} / \mathrm{L}, \mathrm{pH} 6.5)$, was added $0.3 \mathrm{~mL}$ of substrate $(0.1 \mathrm{~mol} / \mathrm{L})$ and $0.3 \mathrm{~mL}$ of tissue homogenate. The reaction mixture was incubated at $37^{\circ} \mathrm{C}$ for one hour after which 1 $\mathrm{mL}$ of the reaction mixture was transferred in to $1 \mathrm{ml} 10 \%$ TCA and then centrifuged. The supernatant $(1 \mathrm{~mL})$ was then added to $1 \mathrm{~mL}$ of ammonium molybdate followed by $0.4 \mathrm{~mL}$ of amino naphthol sulphonic acid (ANSA). The blue color that developed after $20 \mathrm{~min}$ was read at $680 \mathrm{~nm} 21$. Enzymatic activity expressed in $\mu \mathrm{mol} / \mathrm{L}$ of released product/mg of protein as determined from the standard curve of phosphorus solution (1 mM).

\section{Assay of hepatic and renal fructose-1,6-diphosphatase activity}

Fructose-1,6-bisphosphatase (EC 3.1.3.11) activity was measured using the method earlier described by Gancedo and Gancedo ${ }^{22}$. The assay mixture in a final volume of $2 \mathrm{~mL}$ contained $1.2 \mathrm{~mL}$ of Tris-HCl buffer ( $0.1 \mathrm{~mol} / \mathrm{L}, \mathrm{pH} 7.0), 0.1$ $\mathrm{mL}$ of substrate, $0.25 \mathrm{~mL}$ of magnesium chloride, $0.1 \mathrm{~mL}$ of potassium chloride solution, $0.25 \mathrm{~mL}$ of ethylene diamine tetra acetic acid (EDTA) solution and $0.1 \mathrm{~mL}$ of enzyme homogenate and incubated at $37^{\circ} \mathrm{C}$ for $5 \mathrm{~min}$. The action of the enzyme was stopped by $10 \%$ TCA. The suspension was centrifuged and the supernatant was made up to $1 \mathrm{~mL}$. To this, $1 \mathrm{~mL}$ of ammonium molybdate was added followed by $0.4 \mathrm{~mL}$ of ANSA. The blue color that developed after $20 \mathrm{~min}$ of incubation was read at $680 \mathrm{~nm}$. Enzymatic activity expressed in $\mu \mathrm{mol} / \mathrm{L}$ of released product/mg of protein as determined from the standard curve of phosphorus solution (1 mM).

\section{Immunohistochemical analysis of pancreatic structure}

Pancreas of sacrificed animals were fixed in $10 \%$ formalin and used for Immunohistochemistry studies. Immunohistochemical staining was performed on paraffin sections 23. Briefly, each section was immunolabeled for $\beta$-cells, which was accomplished with a monoclonal insulin antibody thereafter secondary biotinylated anti-mouse link antibody was utilized and positive labeling was visualized using the alkaline phosphatase fuchsin method. The primary antibody was omitted in the control samples. All sections were counterstained with Mayers and mounted in Entallen ${ }^{\circledR}$.

\section{Statistical Analysis}

The data was analysed statistically using the GraphPad Prism 7.00 software. The results were expressed as mean \pm SEM of 6 animals. The values were compared using the OneWay Analysis of Variances (ANOVA) test followed by the Tukey multiple comparison test. The differences were considered significant at $\mathrm{P}<0.05$.

\section{RESULTS}

\section{Effect of C. afer extracts on fasting blood glucose concentration of diabetic rats}

Experimental rats administered streptozotocin showed an increase in fasting blood glucose concentration above 200 $\mathrm{mg} / \mathrm{dl}$ and were characterized diabetic. When these diabetic rats were treated with hydro-ethanolic leaf extract DHE 250, DHE 500 and DHE 1000 a successive reduction in blood glucose concentration was observed from week 1 to week 3 (Figure 1) towards normal. All extract concentrations attained normal glucose concentration as compared to the normal control at week 4. Meanwhile the diabetic control animals still showed a significantly $(\mathrm{P}<0.001)$ high glucose concentration compared to the extracts and normal control.

Figure 2 presents the net reduction in blood glucose concentration (percentage reduction) throughout the study. Metformin showed the highest percentage reduction (75.23\%) was not so different from effect of plant extract concentrations DHE 250 (73.23\%), DHE 500, (74.14\%) and DHE 1000 (70.6\%). A net reduction in glucose concentration of the normal and diabetic controls was also observed (3.06\% and $15.46 \%$ respectively) though not comparable to the treated groups. 


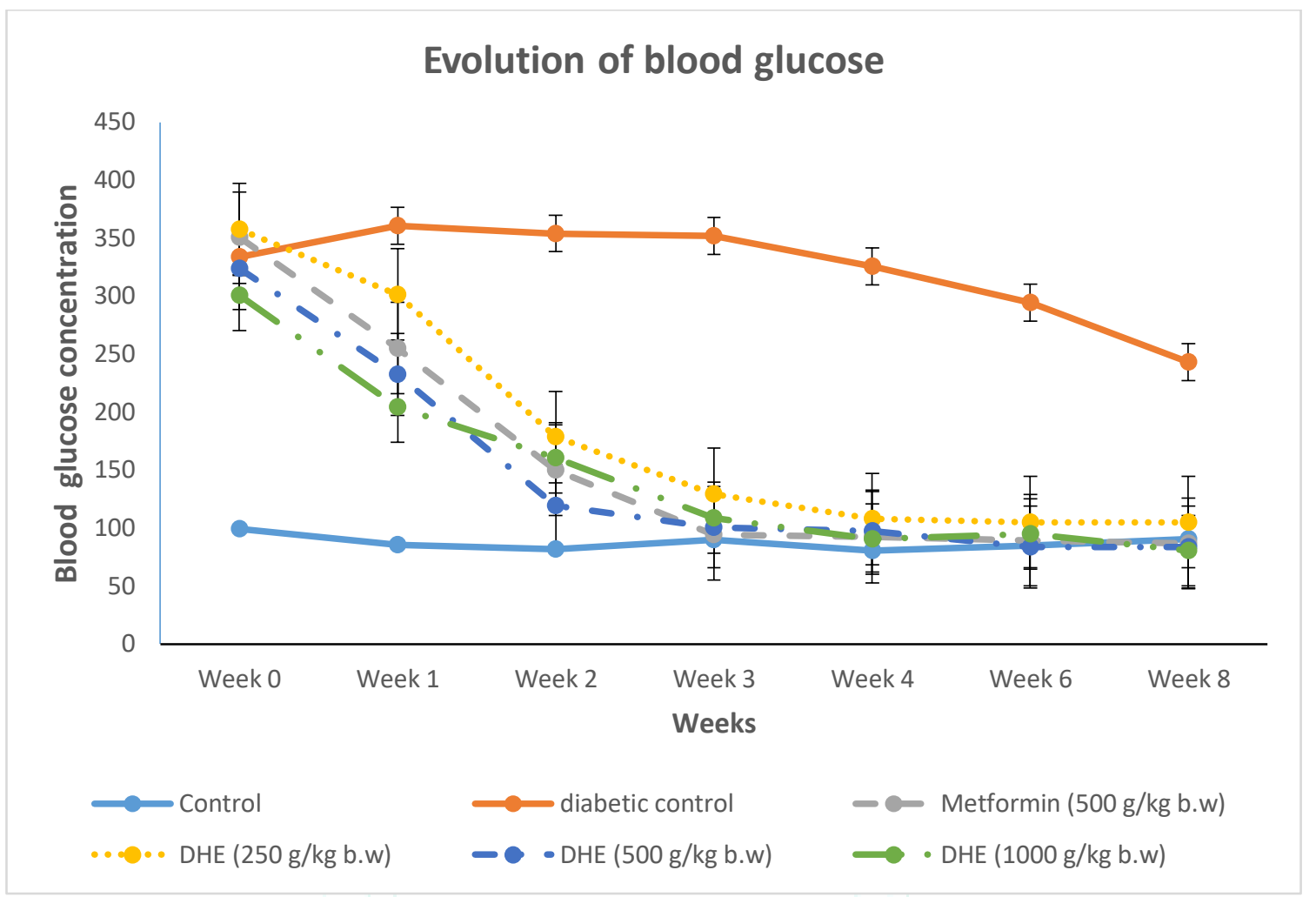

Figure 1: Change in blood glucose concentration in streptozotocin model rats treated with DHE 250, DHE 500 and DHE 1000 as compare to controls. DHE: Diabetic Hydro-ethanolic.

Data are expressed as means \pm S.D $(n=5) .{ }^{* * *} p \leq 0.001$ compared with the corresponding value for control rats.

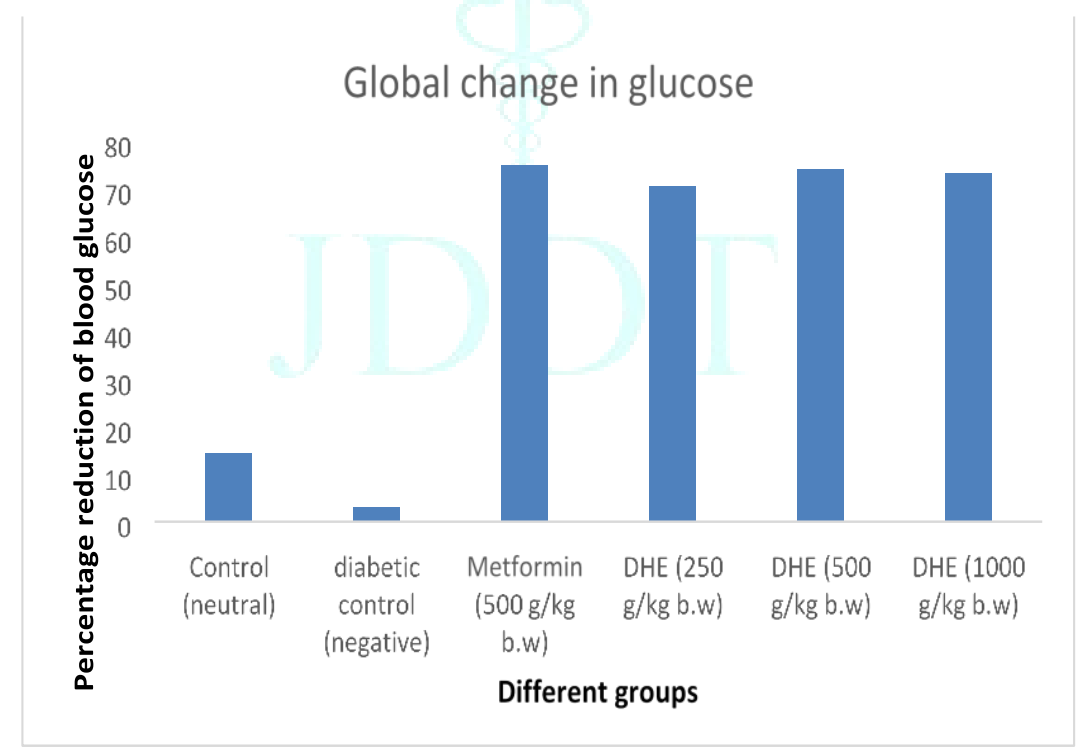

Figure 2: Net percentage reduction in blood glucose concentration of experimental animals in the course of the study.

\section{Effect of $C$. afer and metformin on body weight of streptozotocin treated rats}

Effect of hydro-ethanolic leaf extract $C$. afer and metformin on body weight of STZ-treated rats is presented in Figure 3. A significant $(p<0.05)$ increase in body weight was observed in the normal control animals as compared to the diabetic control. Thus the administration of STZ significantly decreased body weight gain. Treatment with plant extract and metformin significantly inhibited the effect of STZ on body weight and weight gain increased significantly $(\mathrm{p}<0.05)$ towards normal. DHE 500, DHE 1000 had more protective effect than MET 500 the reference drug. 


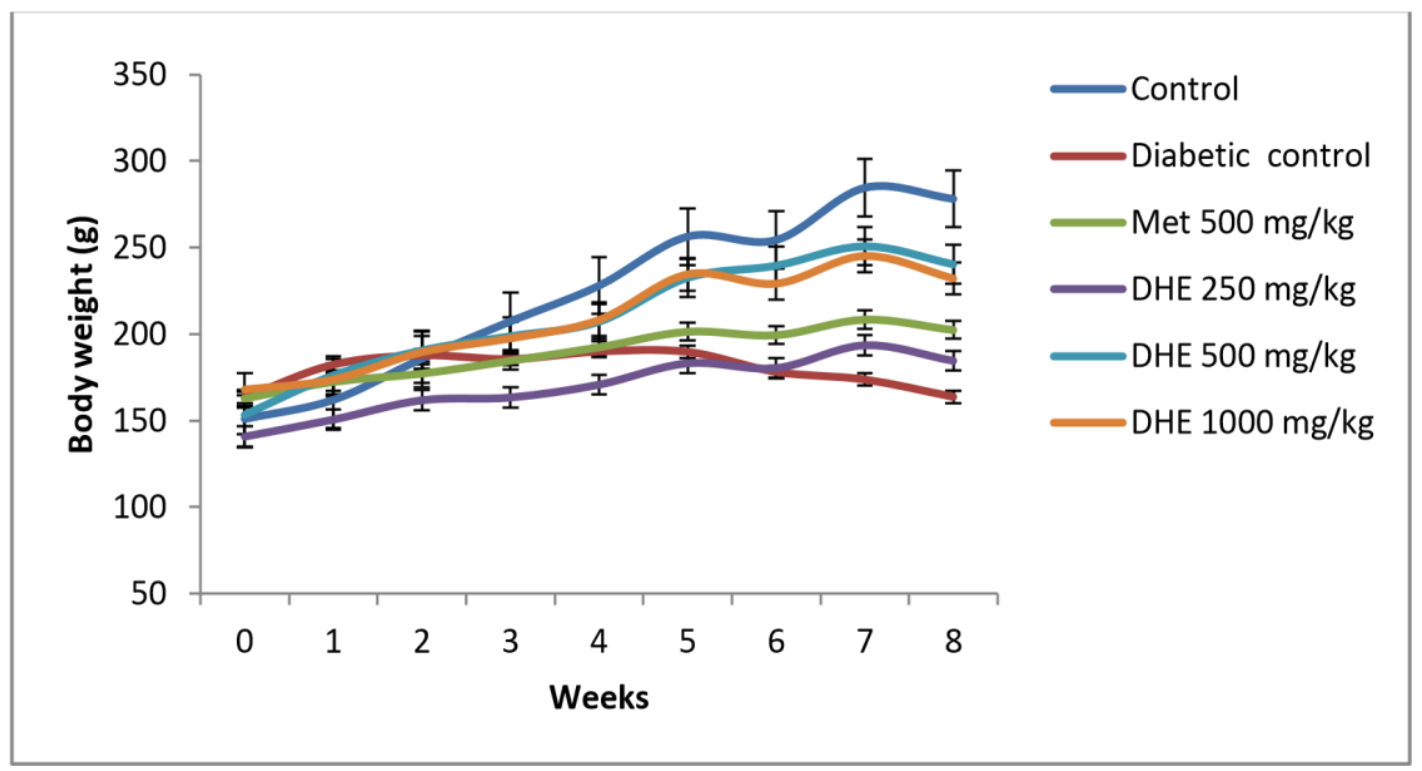

Figure 3: Effect of plant extract and metformin on weight gain in STZ treated animals compared to control.

\section{Effect of $C$. afer and metformin on carbohydrate metabolizing enzymes of STZ treated rats}

Table 1 shows the effect of $C$. afer extract on the activities of $\alpha$-glucosidase, hexokinase, glucose- 6 -phosphatase and fructose-1,6-diphosphatase in streptozotocin-induced diabetic rats. STZ administration significantly reduced the enzyme activity of hexokinase as compared to the normal control. However, administration of $C$. afer extract and metformin to diabetic rats significantly inhibited $(\mathrm{P}<0.05)$ the effect of STZ on this enzyme. DHE 500 and DHE 1000 were the most effective though not comparable to the effect of MET 500 (standard drug). The intestinal $\alpha$-glucosidase activity was significantly increased by STZ administration as shown in the diabetic group of animals. As expected plant extract and metformin equally inhibited $(\mathrm{P}<0.05)$ the effect of STZ on rat intestinal disaccharides activity.

STZ-induced diabetic rats showed a significant increase in the activities of glucose- 6 -phosphatase $(0.730 \pm 0.280$ $\mathrm{U} / \mathrm{min} / \mathrm{mg}$ protein) and fructose-1,6-diphosphatase (5.460 \pm $0.750 \mathrm{U} / \mathrm{min} / \mathrm{mg}$ protein) when compared to normal control rats. However, administration of $C$. afer $(1000 \mathrm{mg} / \mathrm{kg}$ b.w) in diabetic rats significantly reduced the activities of glucose-6phosphatase $(0.27 \pm 0.06 \mathrm{U} / \mathrm{min} / \mathrm{mg}$ protein $)$ and fructose1,6-diphosphatase $(2.01 \pm 0.46 \mathrm{U} / \mathrm{min} / \mathrm{mg}$ protein $)$ as compared to diabetic control rats.

Table 1: Effect of $C$. afer and metformin on the activities of $\alpha$-glucosidase, glucose-6-phosphatase, fructose-1,6-diphosphatase and hexokinase of experimental animals.

\begin{tabular}{|c|c|c|c|c|c|c|c|}
\hline Enzymes & Place & Control & Diabetic & DHE 250 & DHE 500 & DHE 1000 & MET 500 \\
\hline 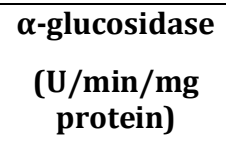 & $\begin{array}{c}\text { Small } \\
\text { intestine }\end{array}$ & $0.49 \pm 0.10^{b}$ & $0.64 \pm 0.09 \mathrm{c}$ & $0.33 \pm 0.08^{\mathrm{ab}}$ & $0.24 \pm 0.05^{\mathrm{a}}$ & $0.26 \pm 0.01^{\mathrm{a}}$ & $0.30 \pm 0.05^{\mathrm{ab}}$ \\
\hline $\begin{array}{c}\text { Hexokinase } \\
\left(\mathrm{U}^{* *} / \mathrm{min} / \mathrm{mg}\right. \\
\text { protein }\end{array}$ & Liver & $4.08 \pm 0.15^{\mathrm{a}}$ & $2.49 \pm 0.55^{b}$ & $3.28 \pm 1.16^{a . b}$ & $4.66 \pm 0.70^{\mathrm{a}}$ & $4.49 \pm 2.21^{\mathrm{a}}$ & $5.76 \pm 0.66^{a}$ \\
\hline $\begin{array}{c}\text { Glucose-6- } \\
\text { phosphatase }\end{array}$ & Liver & $0.32 \pm 0.08^{a}$ & $0.73 \pm 0.28^{b}$ & $0.34 \pm 0.04^{\mathrm{a}}$ & $0.24 \pm 0.05^{\mathrm{a}}$ & $0.27 \pm 0.06^{\mathrm{a}}$ & $0.29 \pm 0.06^{\mathrm{a}}$ \\
\hline $\begin{array}{c}\left(\mathrm{U}^{*} / \mathrm{min} / \mathrm{mg}\right. \\
\text { protein })\end{array}$ & kidneys & $0.24 \pm 0.10^{\mathrm{a}}$ & $0.34 \pm 0.08^{b}$ & $0.30 \pm 0.10^{\mathrm{ab}}$ & $0.23 \pm 0.02^{\mathrm{a}}$ & $0.24 \pm 0.04^{a}$ & $0.27 \pm 0.07^{a}$ \\
\hline \multirow{2}{*}{$\begin{array}{c}\text { Fructose-1,6- } \\
\text { diphosphatase } \\
\text { (U*/min/mg } \\
\text { protein) }\end{array}$} & Liver & $1.70 \pm 0.10^{\mathrm{a}}$ & $5.46 \pm 0.75^{b}$ & $2.04 \pm 0.69 \mathrm{a}$ & $2.14 \pm 0.15^{\mathrm{a}}$ & $2.01 \pm 0.46^{\mathrm{a}}$ & $2.25 \pm 0.4^{\mathrm{a}}$ \\
\hline & kidneys & $0.29 \pm 0.06^{\mathrm{a}}$ & $0.53 \pm 0.18^{b}$ & $0.32 \pm 0.17 \mathrm{a}$ & $0.37 \pm 0.03^{\mathrm{a}}$ & $0.31 \pm 0.08^{\mathrm{a}}$ & $0.42 \pm 0.19 a . b$ \\
\hline
\end{tabular}

$U^{*}=$ moles of inorganic phosphorus liberated; $U^{* *}=$ moles of glucose phosphorylated. Each value is a mean \pm SD of six rats in each group. Values not sharing a common superscript $(a, b, c)$ differ significantly $(p<0.05)$. 


\section{Effect of $C$. afer and metformin on the Islet cells of the pancreas of experimental rats}

The immunohistochemistry examination of pancreatic tissues of experimental animals is presented in Figure 4. In untreated diabetic rats (b) the absence of insulin in the islet cells in pancreas was obvious. Treatment of experimental animals with hydroethanolic extract of C. afer (c) and metformin (d) revealed large surface of immunoreactivity (yellow) indicating the presence of insulin, compared to control in the pancreas of diabetic rats. This surface of immunoreactivity is comparable to normal group (a).
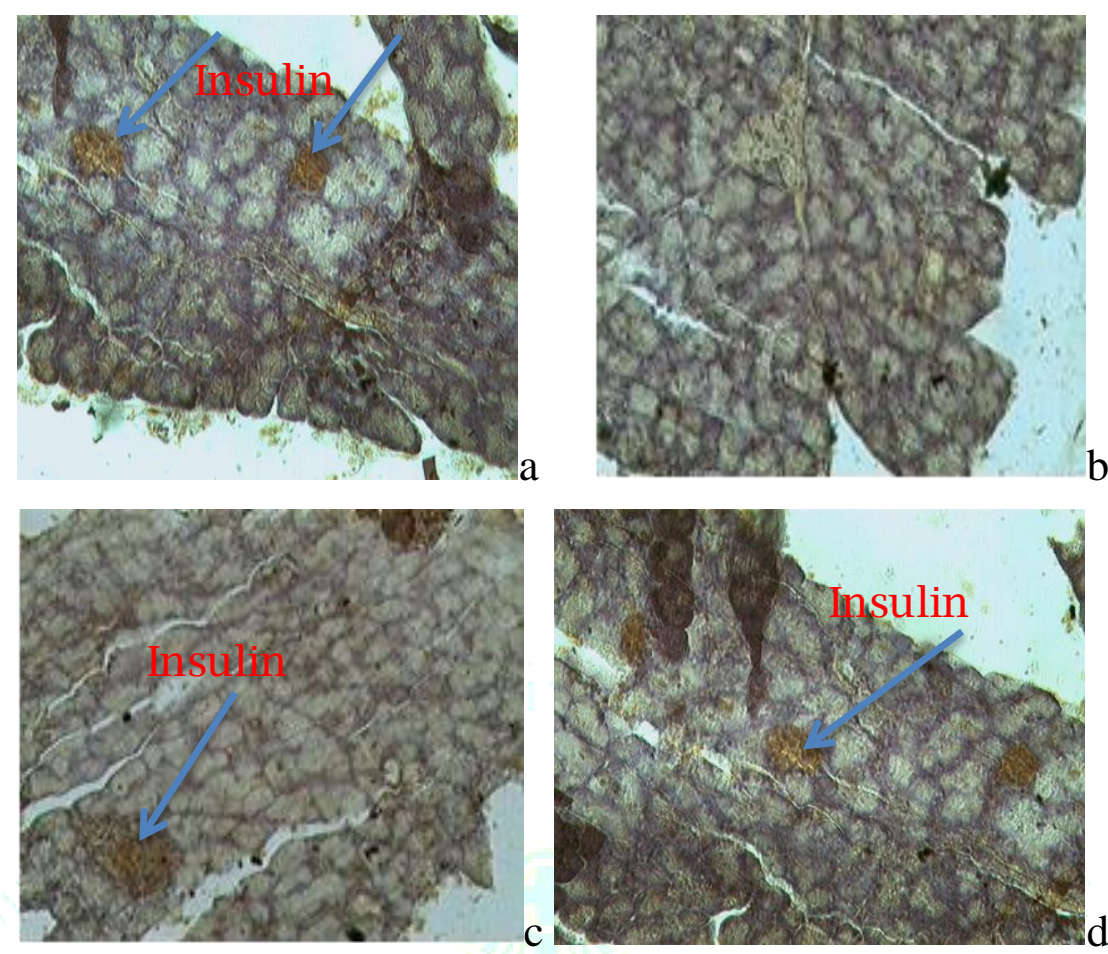

Figure 4: Immuno-histochemical aspect of the pancreas of normal and diabetic control rats after 8 weeks of treatment with $C$. afer and metformin.

\section{DISCUSSION}

Streptozotocin-induced hyperglycemia in animals is considered to be a good model for the preliminary screening of agents active against diabetes and is widely used ${ }^{24}$. It is known for its selective $\beta$-cell toxicity. Streptozotocin (STZ) is a potent DNA methylating agent and acts as a nitric oxide donor in pancreatic cells. $\beta$-cells are particularly susceptible to damage by STZ, a cytotoxic agent 25 . As a result, the expression and secretion of insulin is declined significantly there by leading to hyperglycemia, a clinical hallmark of diabetes. Metformin is often used as a standard antidiabetic drug in streptozotocin induced diabetic rats studies to compare the efficacy of a variety of hypoglycemic compounds/agents 26 .

From the results obtained, it is evident that diabetic rats had much higher glucose level than the control rats. Some substances have shown antidiabetic effect by influencing $\beta$ cell to stimulate insulin secretion and restore insulin sensitivity 27. The present data indicated that C. afer significantly decreased blood glucose levels in treated diabetic rats as compared with control diabetic rats. This may be due to the insulin release of $C$. afer on peripheral tissues, either by promoting glucose uptake and metabolism, or by inhibiting hepatic gluconeogenesis $\mathbf{2 7}$.

Weight lose is one parameter of importance in measuring the improvement of diabetic state. In diabetes mellitus, deranged glucagon-mediated regulation of cyclic AMP formation in insulin deficiency leads to accelerated proteolysis $\mathbf{2 8}$ Normalization of carbohydrate, protein and fat metabolism would alleviate the diabetic symptom of weight loss; therefore, body weight holds one of the key in evaluating the effectiveness of an antidiabetic treatment ${ }^{29}$. The present study also revealed that body weight was increased in the control rats, whereas a significant reduction was observed in diabetic rats. Loss of weight is an indication of the degradation of structural proteins in diabetic situation ${ }^{30}$. $C$. afer and Metformin treatment significantly prevented the loss in the weight. This shows that $C$. afer has the ability to reduce hyperglycemia complication.

The liver is an essential organ in glycolysis and gluconeogenesis for the regulation of blood glucose concentration. A partial or total deficiency of insulin causes derangement in carbohydrate metabolism that decreases the activity and expression of a few key carbohydrate metabolic enzymes such as hexokinase and phosphofructokinase, resulting in impaired peripheral glucose utilization and increased hepatic glucose production contributing to hyperglycemia ${ }^{31}$. Hexokinase is the key enzyme in the catabolism of glucose, which phosphorylates glucose and converts it into glucose-6-phosphate during diabetes; its activity is severely impaired 32 . In the present study, streptozotocin administration significantly inhibited the hexokinase activity. Treatment with $C$. afer and metformin elevated the activity of hexokinase and it is more pronounced in the group treated with C. afer $1000 \mathrm{mg} / \mathrm{kg}$ of bw). C. afer may have stimulated insulin secretion to activate hexokinase activity. This increased activity of hexokinase may stimulate increased glycolysis and utilization of glucose for energy production. A similar study in which plants extracts stimulates the activity of hexokinase has been demonstrated by Ananda et al. 33 . 
Glucose-6-phosphatase plays a key role in blood glucose metabolism by catalyzing the hydrolysis of glucose-6phosphate in the common terminal step of the gluconeogenic and glycogenolytic pathways 34. This is an important regulatory enzyme involved in the release of glucose from the liver and kidneys through a mechanism involving gene expression or inhibition of its enzymatic activity. Fructose 1,6-bisphosphatase is one of the key enzyme of the gluconeogenic pathway. It catalysis the rate limiting step of the conversion of fructose-1,6-bisphosphate to fructose which is necessary for reversal glycolysis $\mathbf{3 5}$. It catalyzes one of the irreversible steps in gluconeogenesis and serves as a site for the regulation of this process ${ }^{36}$. The levels of these two gluconeogenic enzymes (glucose-6-phosphatase and fructose-1,6-bisphosphatase) are increased in diabetic condition. The increase in activity of these gluconeogenic enzymes may be related to insulin deficiency which functions as a suppressor of these enzymes. However, in C. afer treated rats, the activities of glucose-6-phosphatase and fructose1,6-bisphosphatase were maintained towards normal which shows the protective effect of this plant. In the same way, $C$. afer also inhibited activity of intestinal $\alpha$-glucosidase, increased in diabetic control. This result confirmed the previously published data on in vitro inhibitory activity of $C$. afer on carbohydrate metabolizing enzyme ${ }^{14}$.

Immunohistochemistry of the pancreas showed absence of staining for insulin in the $\beta$-cells in diabetic control which was present in the normal control. Absence of $\beta$ cells in untreated diabetic rats may be due to the destructive effect of STZ characterized by degranulation and loss of insulin secretion. While, in the C. afer and metformin-treated rats' immunochemical staining of insulin (yellow color) were observed. Implying that $C$. afer and metformin, can improve the viability of pancreatic $\beta$-cell and induce its regeneration after 8 weeks of treatment. Similar results have been reported by Nwauche et al. ${ }^{37}$, who observed that the islet cells of diabetic rats treated with aqueous stem extract of $C$. afer and in combination with metformin, were repopulated during a nine weeks treatment.

\section{CONCLUSION}

The over production of blood glucose by excessive hepatic glycogenolysis and gluconeogenesis and decreased utilization of glucose by the tissues is a fundamental cause of hyperglycemia in diabetes mellitus. The hydroethanolic extract of $C$ afer administration in diabetic rats induced a reduction in blood glucose concentration which may be due to increased production of insulin in beta cells of pancreas and increased utilization of glucose by tissues. This was characterized by inhibition of the activity of key hepatic gluconeogenic enzymes glucose-6-phosphatase, fructose-1,6bisphosphatase and accelerated rate of glycolytic hexokinase and regeneration of $\beta$-cells. The antidiabetic effect of $C$. afer was comparable to metformin, suggesting its high potential to be developed as a plant-derived antidiabetic agent.

\section{Conflict of Interests}

The authors declare that they have no conflict of interest.

\section{Author's contributions}

ADT: Animal care and laboratory analysis and prepared the manuscript; PDDD: Carried out immunohistochemistry examination; GAA and JRK: Designed, supervised the work and participated in the final version of the manuscript.

\section{REFERENCES}

1. McKee T, McKee, Kristova JR. Biochemistry. The Molecular Basis of Life, In: carbohydrate metabolism, 5 edn. Oxford University Press, USA, 2011; 1:3.

2. Trivedi B, Mazumdar JD, Bhatt, Hemavathi KG. Effect of Shilajit on blood glucose and lipid profile in alloxan-induced diabetic rats. Indian Journal of Pharmacology, 2004; 36 (6):373-376.

3. Ashok K, Madhusudana, Rao J. Diabetes mellitus and multiple therapeutic approaches of phytochemicals: Present status and future prospects. Current Science, 2002; 83:3038.

4. World Health Organization. Definition diagnosis and classification of diabetes mellitus and its complications. World Health Organization, Department of non-communicable disease surveillance, Geneva, Switzerland, 1999.

5. Ashokkumar N, Pari L. Effect of N-benzoyl-D-Phenylalanine and metformin on carbohydrate metabolic enzymes in neonatal streptozotocin diabetic rats. Clinica Chimica Acta, 2005; 351:105-113.

6. Bailey CJ. Potential new treatments for Type 2 diabetes. Trends in Pharmacological Science, 2000; 21:259-265.

7. Shaw JE, Sicree RA, Zimmet PZ. Global estimates of the prevalence of diabetes for 2010 and 2030. Diabetes Res Clin Pract, 2010; 87:4-14.

8. Donner TW. Tight control of hyperglycemia in type 2 diabetes mellitus. Insulin, 2006; 1:166-172.

9. Jain S, Saraf S. Type 2 diabetes mellitus: Its global prevalence and therapeutic strategies. Diabetes Metabolism Syndrom of Clinical Research Revue, 2010; 4:48-56.

10. Chiasson J L, Josse R G, Gomis R, Hanefeld M, Karasik A, Laakso M. Acarbose for prevention of type 2 diabetes mellitus: the STOP-NIDDM randomized trial. Lancet, 2002; 359:2072-2077.

11. Klonoff D C. Incretin therapy for type 2 diabetes mellitus. Advances in Therapy, 2010 27:881-894.

12. Wulffele MG, Kooy A, Lehert P, Bets D, Ogterop JC, Borger VBB, Donker AJ, Stehouwer CD. Effects of short-term treatment with metformin on serum concentrations of homocysteine, folate and vitamin B12 in type 2 diabetes mellitus: a randomized, placebocontrolled trial. Journal of Internal Medicine, 2003; 254:455-463.

13. Bailey CJ, Day C. Traditional plant medicines as treatment for diabetes. Diabetes care, 1989; 553-564.

14. Tchamgoue DA, Tchokouaha YLR, Tarkang AP, Kuiate J-R, Agbor AG. Costus afer possesses carbohydrate hydrolyzing enzymes inhibitory activity and antioxidant capacity In vitro", Evidence-based Complementary and Alternative Medecine, 2015; ID 987984, 10 pages.

15. Tchamgoue DA, Tchokouaha YLR, Domekouo FLU, Atchan NAP, Tarkang AP, Kuiate J-R, Agbor AG. Effect of Costus afer on carbohydrates tolerance tests and glucose uptake. Scholars Academic Journal of Bioscience, 2016; 4 (6):459-469.

16. Mogale MA, Mkhombo HM, Lebelo SL, Shai LJ, Chauke MA, De Freitas. The effects of clausena anisata (wild) Hook leaf extracts on selected diabetic related metabolizing enzymes. Journal of Medicine Plants Research, 2011; 6 (25):4200-4207.

17. Kim YM, Jeong YK, Wang MH, Lee WY, Rhee HI. Inhibitory effect of pine extract on $\alpha$-glucosidase activity and postprandial hyperglycemia. Nutrition, 2005; 21 (6):756-761.

18. Brandstrup N, Kirk JE, Bruni C. Determination of hexokinase in tissues. Journal of Gerontology, 1957; 12:166-171.

19. Trinder P. Determination of glucose in blood using glucose oxidase with an alternative oxygen acceptor. Annals of Clinical Biochemistry, 1969; 6 (1):24-27, 1969.

20. Koida H, Oda T. Pathological occurrence of glucose-6phosphatase in liver disease. Clinica Chemica Acta, 1959; 4:551-561.

21. Fiske $\mathrm{CH}$, Subbarow Y. The colorimetric determination of phosphorus. Journal of Biological Chemistry, 1925; 66:375400 .

22. Gancedo JM, Gancedo C. Fructose-1,6-bisphosphatase, phosphofructokinase and glucose-6-phosphate dehydrogenase from fermenting yeast. Archives of Microbiology, 1971; 76:132-138.

23. Lu WG, Pipeleers DG, Kloppel G, Bouwens L. Comparative immunocytochemical study of MHC class II expression in human donor pancreas and isolated islets. Virchows Archives, 1996; 429:205-211. 
24. Ivorra MD, Paya M, Villar A. A review of natural products and plants as potential antidiabetic drugs. Journal of Ethnopharmacology, 272:243-275.

25. Bach JF (1997). Autoimmunity and type I diabetes. Trends in Endocrinology and Metabolism, 1989; 8:71-74.

26. Prakasam S, Pugalendi KV. Antihyperglycemic activity of Casearia esculenta root extracts in STZ induced diabetic rats. Pharmazie; 2002; 57:11.

27. Yolanda BL, Adriana GC. Effects of dietary polyunsaturated n-3 fatty acids on dyslipidemia and insulin resistance in rodents and humans. Journal of Nutritional Biochemistry, 2006; 17:113.

28. Rajasekaran S, Sivagnanam K, Subramanian S. Mineral contents of Aloe vera leaf gel and their role on streptozotocininduced diabetic rats. Biological Trace Element Research, 2005; 108:185-195.

29. Al-at tar AM, Zari TA. Influences of crude extract of tea leaves, Camellia sinensis, on streptozotocin diabetic male albino mice. Saudi Journal of Biological Sciences, 2010; 17:295-301.

30. Rajkumar L, Govindarajulu P. Increased degradation of dermal collagen in diabetic rats. Indian Journal of Experimental Biology, 1991; 29:1081-1083.

31. Kalaiarasi P, Pugalendi KV. Antihyperglycemic effect of $18 \beta$ glycyrrhetinic acid, aglycone of glycyrrhizin, on streptozotocin-diabetic rats. European Journal of Pharmacology, 2009; 606:269-273.

32. Zhou Hua, Yang Xi, Naili W, Yaou Z, Guoping C. Tigogenin inhibits adipocytic differentiation and induces osteoblastic differentiation in mouse bone marrow stromal cells. Molecular and Cellular Endocrinology, 2007; 12:1731-1736.

33. Ananda PK, Kumarappan CT, Sunil C, Kalaichelvan VK. Effect of Biophytum sensitivum on streptozotocin and nicotinamideinduced diabetic rats. Asian Pacific Journal of Tropical Biomedicine, 2012; 2(1):31-35.

34. Wallert MA, Foster JD, Scholnick DA. Kinetic analysis of glucose-6-phosphatase: an investigative approach to carbohydrate metabolism and kinetics. Biochemistry and Molecular Biology Education, 2001; 29:199-203.

35. Murray RK, Granner DK, Mayes PA. Rodwell V W, "Harper's Biochemistry, 25th ed. Stamford, Connecticut: Appleton and Lange, (2000) pp. 610-617.

36. Tillmann $\mathrm{H}$, Bernhard D, Eschrich $\mathrm{K}$. Fructose-1,6bisphosphtase genes in animals. Gene, 2002; 291:57-66.

37. Nwauche KTG, Monago CC, Anacletus FC. Antihyperglycemic activity of the aqueous extract of Costus afer stem alone and in combination with metformin. European Journal of Biotechnology and Bioscience; 2014; 1(5):19-25. 